\section{BLACK-THROATED BLUE WARBLER AT FT. QU'APPELLE}

About 6 p.m. on October 18, 1961, I was walking home from the office when a small bird flew from the roadside and settled close by in some thick shrubbery. As it did so it uttered a "clicking" or "smacking" note which might have passed as that of a junco. To further the illusion, the sun dipped over the rim of the valley and in the reduced light and the cover of the shrubbery it did appear to be a junco. However, as I stopped to give the bird a second look, it turned and a small white wing patch was clearly visible. In a few seconds it disappeared beyond the shrubbery but I found it very quickly in some lighter growth near by. Here, my expectation that it was a male Black-throated Blue Warbler, was beautifully confirmed as I had an unobstructed view with binoculars from a distance of about 25 feet before it flew off.

This charce encounter was of course quite a thrill but imagine my surprise when, upon returning to work at 9 a.m. the next morning, (October 19th) I found undoubtedly the same bird in exactly the original location of the evening before and watched it searching for food on the ground and in the trees, sometimes as close as about eight feet. It was not seen again on further visits to the area.

The rarity of the Black-throated Blue Warbler in Saskatchewan is indicated by the fact that we are aware of only six previous records for the province, three specimen records and three sight records. The known records are now summarized as follows:

Late May, 1935-sight record of a male at Regina.

Oct. 21, 1936-adult male specimen from Percival.

Sept. 21, 1937-sight record of a male at Eastend.

June and July, 1939 — some sight records at Emma Lake.

Oct. 16, 1955 - immature female specimen from Moose Jaw.
Oct. 26, 1960-adult male specimen from Regina.

Oct. 18 and 19, 1961-sight record of an adult male at Fort Qu'Appelle.

Details of the previous records may be found in the Blue Jay, 14:3, in the Blue Jay, 18:156, in the Birds of Regina (Belcher, 1961) and in the references which those publications have quoted.

It is not at all unlikely that. the above records represent birds which were in migration to and from the Canadian Zone of Saskatchewan and that we will eventually have a nesting record for that area.- E. M. Callin, Fort San.

\section{REPORTS OF BALD EAGLES FROM LAC LA RONGE}

Although it was late in the season when we received the Audubon Society's Bald Eagle survey forms, we were able to get some data on eagles in the area. The map shows seven locations in which eagles were seen on a two-hour trip; we feel that each of these represented actual family sites, not movements of one group to äifferent locations. This means an increase in families from four to seven over last year's count. -Ken R. Hurns, Halcyon Camp, Lac La Ronge.

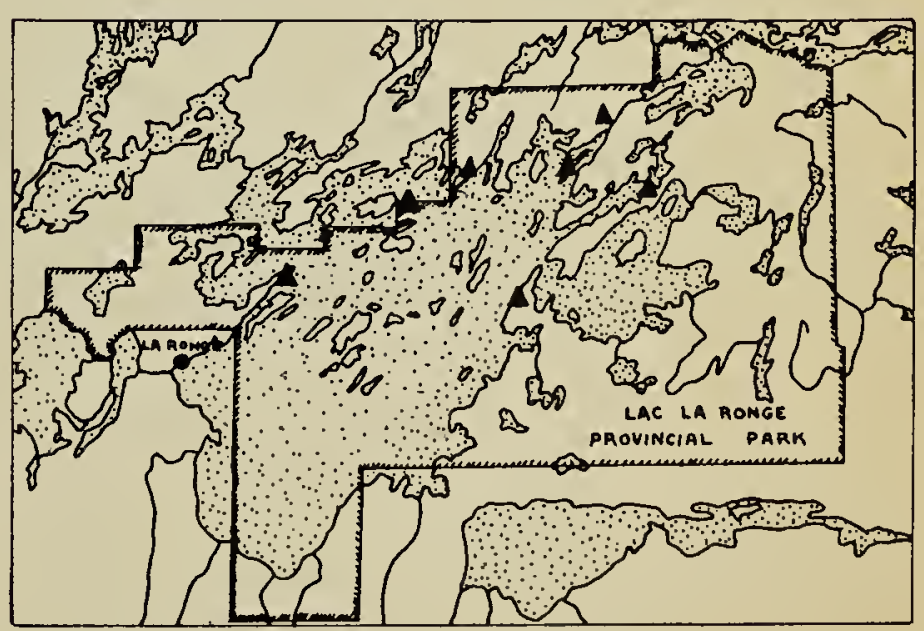

